\title{
Amplification, Cloning and In silico Prediction of Full Length Elicitin Gene from Phytophthora capsici, the Causal Agent of Foot Rot Disease of Black Pepper
}

\author{
Vijesh Kumar IP ${ }^{1 *}$, Reena $\mathbf{N}^{1}$, Anandaraj $\mathbf{M}^{2}$, Eapen SJ1, Johnson $\mathrm{GK}^{3}$ and Vinitha KB ${ }^{1}$
}

${ }^{1}$ Division of Crop Protection, Indian Institute of Spices Research, Calicut, Kerala, India

${ }^{2}$ Director, Indian Institute of Spices Research, Calicut, Kerala, India

${ }^{3}$ Division of Crop improvement and Biotechnology, Indian Institute of Spices Research, Calicut, Kerala, India

\begin{abstract}
Elicitins are a family of small proteins secreted by Phytophthora, which induce leaf necrosis in infected plants. Here, we report the cloning of Elicitin gene from $P$. capsici, an Oomycete plant pathogen which causes significant damage to a broad range of host plants. Elicitin sequence was amplified using primers designed from the known Elicitin genes of other Phytophthora organisms based on their conserved motifs. The PCR amplified product size of $256 \mathrm{bp}$ length and the BLAST analysis of the sequenced product showed perfect match with alpha-elicitin sequences of $P$. capsici. Subsequently, attempt was made to characterize the complete gene of elicitin from genome sequence information of $P$. capsici, by querying the amplified product against the genome. Local BLAST search against full genome identified entire coding sequence. Further sequence analysis identified promoter sequence, transcription start site, a leader signal sequence and a core elicitin domain, with a conserved 6 Cysteine residues. In addition, the three dimensional structure of capsicein was modelled, and the binding affinity of sterol and capsicein was studied using molecular docking. The developed model predicted strong binding affinity for Tyr 47.
\end{abstract}

Keywords: Elicitin; P. capsici; Cloning; In silico

\section{Introduction}

The genus Phytophthora comprises over 100 phytopathogenic species, although 100-500 undiscovered species are estimated to exist [1]. Phytophthora are classified as oomycetes, a diverse group of funguslike eukaryotes that share phylogenetic similarity with brown algae and diatoms $[2,3]$.

A common feature of many different types of plant pathogens is the secretion of a variety of extracellular effectors or elicitor molecules into the plant apoplast [4]. Many of these proteins, called elicitors elicit plant defense responses, and, in particular, a form of programmed cell death called the hypersensitive response (HR). Phytophthora species ubiquitously secrete a unique class of highly conserved effector molecules named elicitins. Elicitins are widespread in Phytophthora species and closely related Pythium species [5]. Elicitins are low molecular weight proteins $(10 \mathrm{kDa})$ secreted into liquid minimal medium [6]. Two classes of elicitins have been identified; alpha-elicitins, which are acidic and induce only necrosis, whereas beta-elicitins are basic and also induce distal necrosis [7]. Acidic elicitins (capsicein and parasiticein) are reported from $P$. capsici and $P$. parasitica respectively, while basic-elicitin (cryptogein and cinnamomin) are from P. cryptogea and P. cinnamomi, respectively. Five classes of elicitin have been defined from the primary structure. Class IA and Class IB encompass elicitin with only the elicitin domain and are 98-amino acid-long proteins. Class II contains HAE (hyperacidic elicitin), with a short hydrophilic C-terminal tail and 103-104 amino acid long ORFs. Class III contains elicitin sequence about 165-170 amino acid long that consist of 98amino acid elicitin sequence and $\sim 70$ amino acid long C-terminal domain, which represents an O-glycosylated domain. Elicitins from Pythium spp. have been classified into a distinct Pythium spp. group [8]. The elicitin from P. capsici known as capsacein belong to class IA.

These various types of elicitor molecules induce biochemical changes as part of the resistance response. Electrolyte leakage, oxidative burst, production of phytoalexin and PR proteins, and increased biosynthesis of ethylene have been described in leaf tissue treated with non-specific elicitors [9], and with specific elicitors. Treatment of suspension cultured tobacco cells with elicitins from P. megasperma leads to rapid protein phosphorylation, $\mathrm{Ca}^{2+}$ influx, extracellular and transient $\mathrm{H}_{2} \mathrm{O}_{2}$ production, alkylinization of the extracellular medium, acidification of the cytosol, lipid peroxidation, gene expression, disruption of microtubular cytoskeleton and cell wall modification $[10,11]$.

Elicitins are also sterol carrier proteins which bind sterols and catalyze their transfer between membranes [12]. The initial complex of elicitin binding to sterols was confirmed by the crystal structures of cryptogein in complex with dehydroergosterol (DHE) [13]. Binding of elicitin to ligands appears to be essential for induction of a biological response in plants [14]. Interaction between the protein and ergosterol involves several residues, among which tyrosine residues are the most denoted [15].

Although, elicitin gene has been cloned and sequenced from $P$. capsici infecting Nicotiana glutinosa [16], there is no report on cloning of elicitin from $P$. capsici infecting black pepper. Despite the identification of elicitin gene from P. capsici, transcription start site (TSS) and promoters for the elicitin (capsicein) have not been clearly identified.

${ }^{*}$ Corresponding author: Vijesh Kumar IP, Division of Crop Protection, Indian Institute of Spices Research, Calicut, Kerala, India, E-mail: vijeship2000@yahoo.co.in

Received May 27, 2013; Accepted June 18, 2013; Published June 24, 2013

Citation: Vijesh Kumar IP, Reena N, Anandaraj M, Eapen SJ, Johnson GK, et al (2013) Amplification, Cloning and In silico Prediction of Full Length Elicitin Gene from Phytophthora capsici, the Causal Agent of Foot Rot Disease of Black Pepper. J Plant Pathol Microb 4: 181 doi:10.4172/2157-7471.1000181

Copyright: ( 2013 Vijesh Kumar IP, et al. This is an open-access article distributed under the terms of the Creative Commons Attribution License, which permits unrestricted use, distribution, and reproduction in any medium, provided the original author and source are credited. 
Citation: Vijesh Kumar IP, Reena N, Anandaraj M, Eapen SJ, Johnson GK, et al. (2013) Amplification, Cloning and In silico Prediction of Full Length Elicitin Gene from Phytophthora capsici, the Causal Agent of Foot Rot Disease of Black Pepper. J Plant Pathol Microb 4: 181 doi:10.4172/2157-7471.1000181

In this paper, we report the amplification, cloning and complete gene information of elicitin gene from $P$. capsici infecting black pepper. In addition, we used the complete genome sequence information of $P$. capsici to identify the Transcription Start Site (TSS) and promoters. Further, the docking analysis revealed the binding mode of capsicein and ergosterol at atomic level. Data presented here provide the first in silico structural description of alpha elicitin-sterol interaction of $P$. capsici infecting black pepper.

\section{Materials and Methods}

\section{Culturing Phytophthora}

Ten mm discs were cut from 4-day old cultures of Phytophthora capsici (culture nos: 98-177, 03-10, 05-14, 06-17, 96-03, 96-09, 96-10, 98-185, 05-03, 97-11 and 99-144 grown in carrot agar, and transferred to $100 \mathrm{ml}$ of Ribeiros medium amended with $100 \mu \mathrm{l}$ of thiamine solution $(1 \mathrm{mg} / \mathrm{ml})$. This was allowed to grow for five days, and then the grown up mycelium was used for DNA extraction.

\section{Nucleic acid extraction}

DNA was isolated from the following isolates viz. 98-177, 03-10, 05 14, 06-17, 96-03, 96-09, 96-10, 98-185, 05-03, 97-11 and 99-144, using protocol [17]. The mycelium was first dried on a sterile filter paper and $100 \mathrm{mg}$ of mycelium was crushed using glass powder in sterile microfuge tubes, using a micropestle in STE buffer ( $1 \mathrm{M}$ Tris-cl pH 8, 5 $\mathrm{M} \mathrm{NaCl}, 0.5 \mathrm{M}$ EDTA and 10\% SDS). Phenol:Chloroform:Isoamylalco hol (Sigma) extraction was done followed by isopropanol precipitation to get the DNA, and later the DNA was purified using RNase $(5 \mathrm{mg} /$ $\mathrm{ml}$ ) (Fermentas). The DNA was finally quantified using biophotometer (Eppendorf).

\section{Oligonucleotide primer designing}

For primer designing, the elicitin nucleotide sequence from $P$. infestans was used initially to do a Blastn database search for homologous elicitin genes in other Phytophthora species. Multiple sequence alignment was performed using ClustalW to align the sequences, and to locate well conserved regions. Primers were designed based on the conserved regions and primer properties were studied using OligoCalc.

\section{PCR amplification and cloning}

Elicitin genes from $P$. capsici were amplified by polymerase chain reaction (PCR), using primer ELICPHYF6 and ELICPHYR6: AGCATCCTCTCGGACTCGT, CGAGAACCCGTTCGCGTA. About 100 ng of DNA was taken for PCR amplification along with $2 \mu \mathrm{l}$ of $10 \mathrm{X}$ taq buffer (Bangalore Genei), $1 \mu \mathrm{l}$ of forward and reverse primers, 10 picomole (Sigma Genosys), $0.3 \mu$ of Taq polymerase (Bangalore Genei) 1.5 units, $0.75 \mu \mathrm{l}$ of $10 \mathrm{mM}$ dNTP (Fermentas) in a total volume of 25 $\mu \mathrm{l}$. The reaction conditions were $94^{\circ} \mathrm{C}$ for 2 minutes initial hold, and then, $94^{\circ} \mathrm{C}$ for 30 seconds, $55^{\circ} \mathrm{C}$ for one minute, $72^{\circ} \mathrm{C}$ for 1 minute for about 30 cycles, and a final extension at $72^{\circ} \mathrm{C}$ for about 10 minutes. The amplified fragment was cloned in a T/A cloning vector (Fermentas). Both the clones, as well as the PCR product from all the isolates, were sequenced using Sanger sequencing at SCIGENOM, Cochin, India. The sequencing results were analysed through BLAST programme.

\section{Search for full length elicitin (capsicein) gene}

A local BLAST search against the complete genome of $P$. capsici was made to search for the complete elicitin gene sequence using Bioedit [18]. The Indian initiative of sequencing the complete genome of P. capsici was taken up by Indian Institute of Spices Research (IISR), funded by Indian Council of Agricultural Research (ICAR). For this, a native isolate of Phytophthora (Is. No. 98-93) infecting black pepper was completely sequenced using next generation sequencing platform, Illumina-Solexa GA II. The complete genome of $P$. capsici was taken as a reference, and the amplified elicitin sequence was queried against the complete genome using Bioedit. The positive match was annotated to find the portion coding for elicitin gene.

\section{Sequence analysis of capsicein}

An upstream gene search was done to look for the promoters and transcription start site, using Neural Network Promoter Prediction tool [19]. The complete CDS of elicitin sequence was subjected to protein domain analysis, using Interproscan [20], and disulfide bonds were found out using Disulfind tool [21]. The probable signal sequence was predicted using SignalP [22]. To further consider the relationship between capsicein and elicitins from different Phytophthora species, a phylogenetic analysis of 26 elicitins and elicitin like sequences were carried out by the neighbour joining method using MEGA5 [23].

\section{Homology modelling of capsicein}

Certain Class IA and Class IB elicitins bind sterols and lipids, and act as sterol carrier proteins. Thus, in order to study the sterol binding activity, an attempt was made to model the three dimensional structure of capsicein. Homology modelling of capsicein was performed using Modeller 9v8. Beta-cryptogein chain A (PDB id: 1BXM) was used as template to generate the three-dimensional structure of capsicein. Elicitins also behave like sterol carrier proteins. Hence, to predict whether P. capsici elicitin can bind to ergosterol, the docking program Molegro Virtual Docker (MVD) [24] was used. The capsicein protein was prepared by MVD and ergosterol was cleaned and optimized using Argus Lab. The 3-D structure of docked complex and the binding mode was analyzed using MVD.

\section{Results}

\section{Cloning of elicitin (capsicein) sequence}

The PCR amplified product size was about $\sim 256$ bp (Figure 1). BLAST analysis of the sequenced product showed perfect match with alpha-elicitin sequences from $P$. capsici present in the NCBI database. The sequence was deposited in NCBI and the accession number is Accession No: JF495405. The blast analysis of the sequence (Accession no: JF495405) revealed a perfect match with alpha elicitin capsicein mRNA from P. capsici showing $96 \%$ homology.

Determination and analysis of full length elicitin (capsicein) gene

Local BLAST search of amplified product against complete genome of $P$. capsici showed a perfect match to Scaffold 38. Further annotation

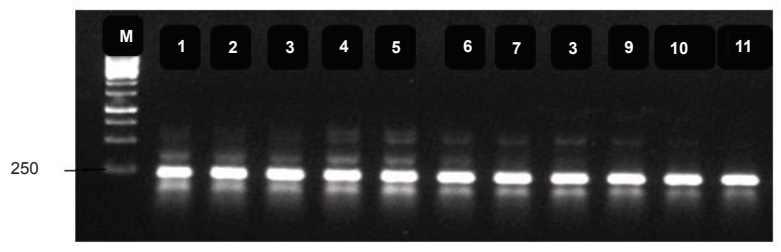

Figure 1: Amplified product of elicitin gene: $\mathrm{M}-1 \mathrm{~kb}$ ladder, lane 1:, 98-177, lane 2: 03-10, lane 3: 05-14, lane 4: 06-17, lane 5: 96-09, lane 6: 96-09, lane 7: 96-10, lane 8: 98-185, lane 9: 05-03, lane 10: 97-11, lane 11: 99-144. 
Citation: Vijesh Kumar IP, Reena N, Anandaraj M, Eapen SJ, Johnson GK, et al. (2013) Amplification, Cloning and In silico Prediction of Full Length Elicitin Gene from Phytophthora capsici, the Causal Agent of Foot Rot Disease of Black Pepper. J Plant Pathol Microb 4: 181 doi:10.4172/2157-7471.1000181

Page 3 of 6

1 TTCTTTQQTA AYVALVSILS DSSFNQCATD SGYSMLTATA LPTTAQYKLM CASTACNTMI 61 SKIVSLNPPD CELTVPTSGL VLNVYSYANG FSATCASL

Figure 2: Phytophthora capsici elicitin complete CDS.

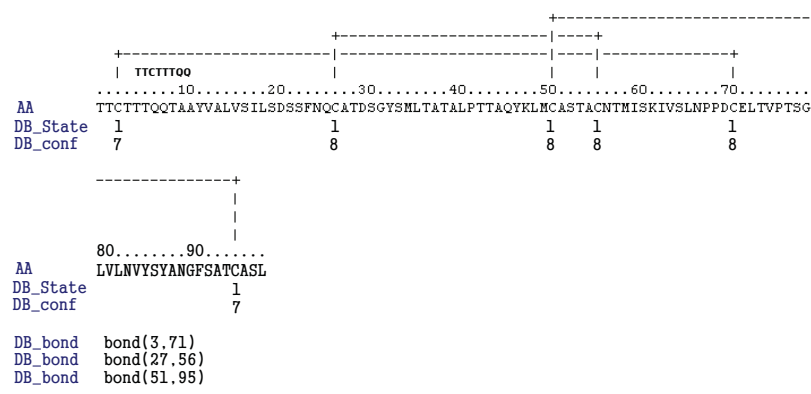

Figure 3: Cysteine disulfide bonding state and connectivity in P. capsici elicitin.

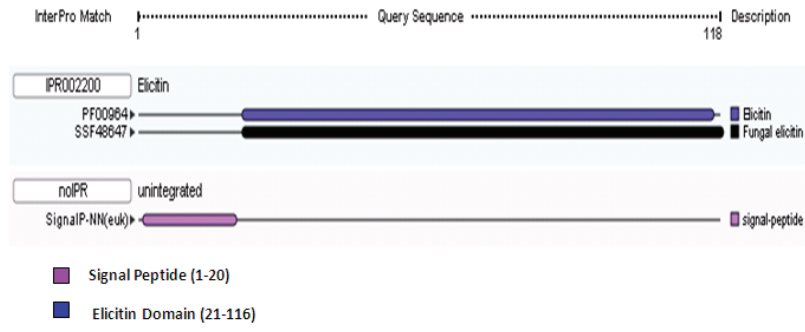

Figure 4: Complete coding sequence showing a leader signal sequence and a core elictin domain of $P$. capsici elicitin.

of the matched region identified the portion coding for elicitin gene. Translation of the coding region gene identified 118 amino acid length elicitin gene, without any introns (Figure 2)

BLAST search of the protein sequence showed a perfect match to alpha elicitin of $P$. capsici. The predicted isoelectric point was 4.68 and the N-terminal portion has Valine at position 13. Disulfind tool predicted the cysteines disulfide bonding state and connectivity as follows: Cys3-Cys71, Cys27-Cys56 and Cys51-Cys95, which is characteristic of elicitin (Figure 3) [14,25]. InterproScan identified a typical elicitin domain of length 95 amino acid length from $\mathrm{T}^{21}$ to $\mathrm{A}^{116}$, which lacked protein kinase C-dependent phosphorylation sites found in the carboxy-terminal region of basic elicitins (Figure 4) [26]. Like other elicitins, capsicein contains 10 Leu, 6 Cys and 3 Met, and lacks Trp, His and Arg. Capsicein comprise only a signal peptide and an elicitin domain.

\section{TSS analysis and promoter prediction}

Alignment of relative TSS of various elicitin genes indicates a conserved amino acid pattern between the TSS of alpha and beta and HAE elicitins (Figure 5) [26]. Consensus TSS pattern of alpha elicitin [GCCATTGTGCA] was searched in the upstream portion of elicitin gene, and the transcription start site of capsicein was located 50 base pairs upstream of first start codon.

Further, sequence analysis was performed upstream the TSS to locate the promoter. However, sequences related to TATA boxes were found 900-930 bp upstream of TSS (Figure 6).

$\begin{array}{ll}\text { B-CRY } & \text { CTCATTCTGCAATTTC ccagtcac } \\ \beta-C I N & \text { CTCATTCTGCAATTgGC tccgtcac } \\ & \\ \alpha-C R Y & \text { GCCATTGTGCAATTTGC tctgtcac } \\ \alpha-C I N & \text { GGCATTGTGCAATTTGC tctgtcgc } \\ \alpha-\text { PAR } & \text { GCCATTGTGCAATTTGC tctcatcC }\end{array}$

HAE-CRY1
HAE-CIN1
HAE-CRY2
HAE-CIN2

CTCATTCCTCAATTTC cttgccaa
CGCACTCCACAATTTGa atttgcC
CTCACTCCACAATTTGC cttgccaa
TTCATTCTGCAATTTC tttgccga

Figure 5: Conserved amino acid pattern of TSS of elicitins. TSS is underlined.

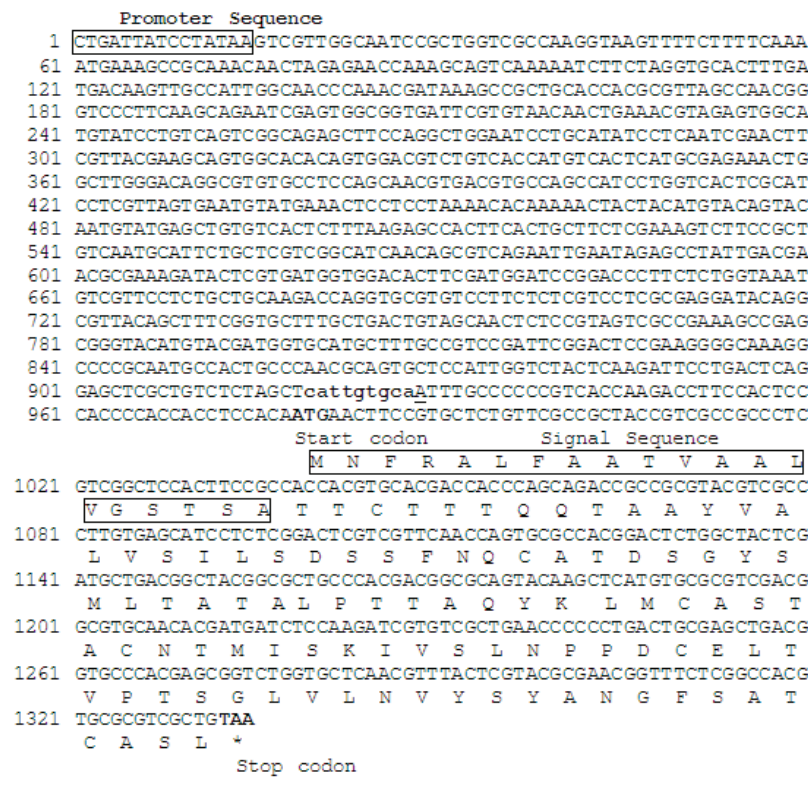

Figure 6: Complete gene characterization of capsicein. Transcription Start site is underlined. The transcription initiation consensus sequence is indicated in lowercase.

\section{Phylogenetic analysis}

Phylogenetic tree of the elicitin from P. capsici and 25 other elicitin and elicitin like sequences from other oomycete species is shown in Figure 7. Phylogenetic analysis of elicitins shows a clear classification into five groups based on their domain characterization.

\section{Homology modelling and docking studies}

Certain Class IA and Class IB elicitins bind sterols and lipids, and act as sterol carrier proteins [27]. Thus, in order to study the sterol binding activity, an attempt was made to model the three dimensional structure of capsicein. The modelled three dimensional structure of elicitins composed of two antiparallel sheet and five helices (Figure $8 \mathrm{a})$. The overall quality of the structure analysed by Ramachandran plot, confirms $97.7 \%$ residues in the allowed regions (Figure 8b). The main elements of secondary structure of capsicein are a two-stranded, 
Citation: Vijesh Kumar IP, Reena N, Anandaraj M, Eapen SJ, Johnson GK, et al. (2013) Amplification, Cloning and In silico Prediction of Full Length Elicitin Gene from Phytophthora capsici, the Causal Agent of Foot Rot Disease of Black Pepper. J Plant Pathol Microb 4: 181 doi:10.4172/2157-7471.1000181

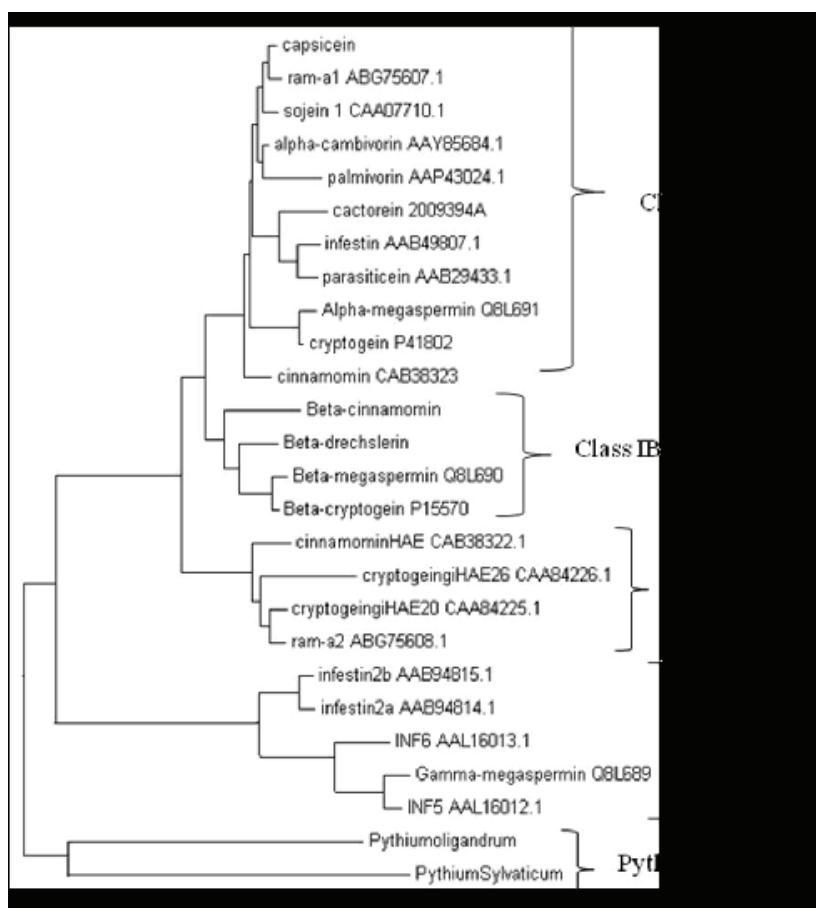

Figure 7: Phylogenetic analysis of the elicitin family proteins from Phytophthora spp. and Pythium.

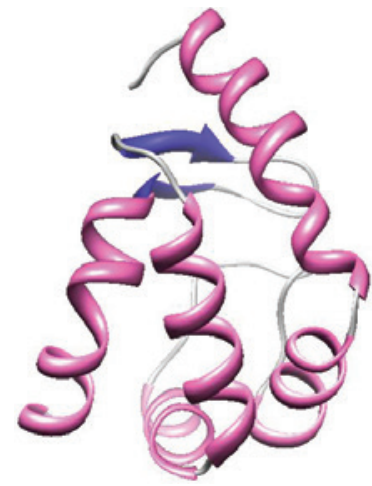

Figure 8a: Predicted three-dimensional structure of capsicein

antiparallel sheet, consisting of residues Leu $73-\mathrm{Thr} 74$ and Val 81-Leu 82. Five helices consisting of residues Thr5-Ser20, Ser22-Ser31, Thr44Ala52, Thr54-Leu 66 and Val84-Ser97 from N to the C terminus.

Ergosterol binds to the groove located inside the cavity of capsicein. Figure 9 shows the hydrogen bond between ergosterol and Tyr 47, correctly identified by docking.

Ergosterol bound to the cavity interacts mainly with the residues making a groove: Tyr 47, Tyr 12, Leu 41, Ile 63, and Met 35. Among which Tyr 47 binds with the least MolDock score of - 118.514 (Table 1), and hence, has better binding affinity for elicitin, and is very important.

\section{Discussion}

Despite the importance of Phytophthora species as devastating plant pathogens, the molecular mechanism that determines the outcome of interactions between Phytophthora and plants is to be fully elucidated.

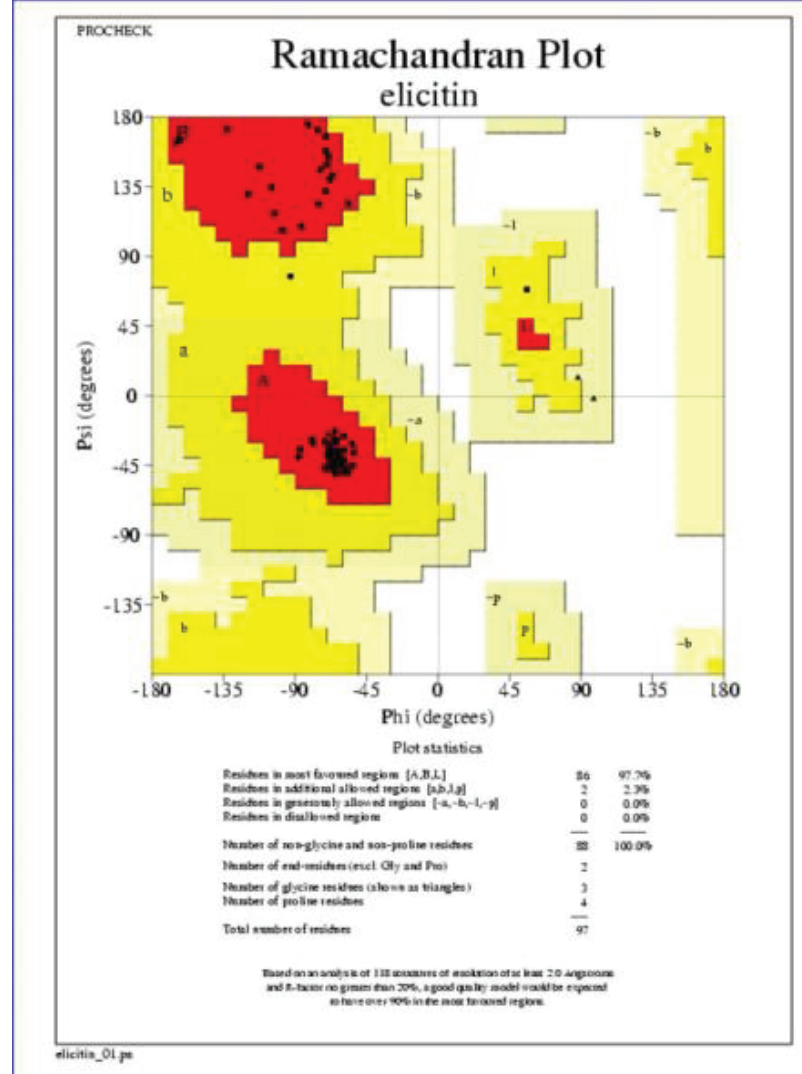

Figure 8b: Predicted Ramachandran plot.

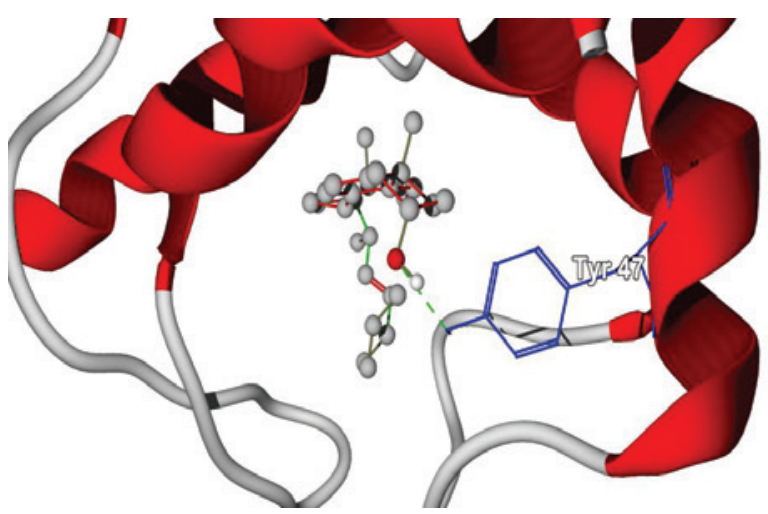

Figure 9: Ergosterol docked to cavity of capsiciein. Hydrogen bond between Tyr 47 and Ergosterol shown in green dotted.

Many plant pathogens secrete a variety of elicitor molecules into plant apoplast [4]. Most of the Phytophthora species and some Pythium species ubiquitously secrete a unique class of highly conserved effector molecules named elicitins, which elicit plant defense responses, and in particular, a form of programmed cell death called hypersensitive response (HR) [5]. Here, we report the cloning and in silico prediction of full length elicitin gene from $P$. capsici, the causal agent of foot rot disease of black pepper.

A 256 base pair PCR amplified product was cloned, sequenced, and BLAST analysis of the sequence showed perfect match with alphaelicitin sequences from $P$. capsici. This sequence was compared to the 
Citation: Vijesh Kumar IP, Reena N, Anandaraj M, Eapen SJ, Johnson GK, et al. (2013) Amplification, Cloning and In silico Prediction of Full Length Elicitin Gene from Phytophthora capsici, the Causal Agent of Foot Rot Disease of Black Pepper. J Plant Pathol Microb 4: 181 doi:10.4172/2157-7471.1000181

\begin{tabular}{|l|l|l|}
\hline S. No. & Residue & MolDock Score \\
\hline 1 & Tyr 47 & -118.514 \\
\hline 2 & Met 35 & -114.682 \\
\hline 3 & Ile 63 & -109.994 \\
\hline 4 & Leu 41 & -107.507 \\
\hline 5 & Tyr 12 & -102.917 \\
\hline
\end{tabular}

Table 1: MolDock Score of residues of capsicein interacting with ergosterol.

genome sequence information data of $P$. capsici by setting up a local BLAST search, which indeed showed perfect match with Scaffold 38 of the genome sequence data. Annotation was done further and matching region identified as the portion coding for elicitin gene. Translation of the coding region identified a 118 amino acid length elicitin gene, which lacked any introns in it. However, splicing probably occurs in some genes of $P$. infestans and $P$. parasitica $[28,29]$. Intron-exon boundary analyses indicated that splicing in Phytophthora is similar to other higher organisms [30].

BLAST search of the protein sequence showed a perfect match to alpha elicitin of $P$. capsici. The predicted isoelectric point of 4.68 and $\mathrm{N}$-terminal sequence with Val at position 13 are consistent with the class acidic a elicitins [31]. Amino acid residue 13 is correlated with necrotic activity of elicitins. The beta elicitins contain a basic lysine residue, which is more necrotic, whereas alpha elicitins contain a hydrophobic valine residue at this position [32]. Though alpha and beta elicitins differ in their levels of necrotic activity, they induce similar levels of resistance [33]. The likely 20 amino acid length signal sequence was predicted to be $\mathrm{M}^{1}$ to $\mathrm{A}^{20}$. The signal peptide is highly conserved $18-20$ amino acids sequence. Elicitins are synthesized as pre-proteins, which undergo post translational modifications through the removal of signal peptides $[5,8]$. Disulfind tool predicted the cysteine disulfide bonding state and connectivity characteristic to elicitin. The even number of cysteine residues can induce defence response in plants, and disulfide bridges formed by the cysteine residues are essential for HR induction and avirulence function [34,4]. The disulfide bridges might enhance stability in the plant apoplast, known to be rich in degradative proteases [35]. InterproScan identified a typical elicitin domain of length 95 amino acid length, which lacked protein kinase $\mathrm{C}$-dependent phosphorylation sites found in the carboxy-terminal region of basic elicitins [26]. Like other elicitins, capsicein contains 10 Leu, 6 Cys and 3 Met, and lacks Trp, His and Arg. All elicitins share a 98 amino acid elicitin domain, with a conserved six cysteine residues. Capsicein comprise mainly a signal peptide and an elicitin domain. This class I elicitins are typically abundant, soluble, secreted proteins in mycelia cultures, and have the ability to transfer sterols [12], or bind phospholipids [14].

Elicitin genes, like other genes of Phytophthora, share a consensus transcription start site (TSS) [36,37]. TSS pattern of alpha elicitin [GCCATTGTGCA] was searched in the upstream portion of elicitin gene, and the transcription start site of capsicein was located 50 base pairs upstream of first start codon. Further, sequence analysis was performed upstream the TSS to locate the promoter. Sequences related to TATA boxes were found $900-930 \mathrm{bp}$ upstream of TSS. The hypothesis put forward here, concerning the promoter is that the promoters of capsicein are found 900-930 bp upstream of TSS.

Phylogenetic analysis of elicitins from different Phytophthora spp. shows a clear classification into five groups based on their domain characterization. The proteins belonging to Class IA and Class IB appeared on separate cluster in the tree, confirming the division of elicitins as acidic and basic [8]. The highly acidic elicitins, having a short hydrophilic C-terminal tail, appeared on significantly distinct branch as class II. The INF2A, INF2B, INF6, INF5 and $\gamma$-megaspermin clustered as Class III. Class III elicitins consists of elicitin domain and O-glycosylated domain. Elicitins like proteins belonging to Pythium groups formed a separate cluster in the phylogenetic tree [8].

Elicitins act as sterol carrier proteins [27]. Homology modelling and docking studies showed how sterol binds to the groove located inside the cavity of capsicein. In this work, a possible link between the elicitor activity of capsicein and its efficiency to load sterols, with the use of molecular docking were performed. Interaction between the protein and ergosterol involves several residues, among which, tyrosine residues are the most significant [15]. In latest reports [38], it indicates that Tyrosine-47 residue is involved in the sole hydrogen bond between the protein core and the sterol. Moreover, the sterol seems to contact its aromatic ring. Replacement of tyrosine residues significantly affected both the interaction rate and the equilibrium concentration of the elicitin-sterol complex. Mutation of tyrosine to phenylalanine increases the steric hindrance, and results in less stable complex. Phytophthora and Pythium do not synthesize sterols, required for their reproduction [39]. Elicitin acts as a shuttle, carrying sterols from the host. Moreover, elicitin-sterol complex formation is required to trigger defense mechanism [38], in plant. The information gained from this study, while limited, provides useful possibilities for further research on alpha elicitins.

\section{Acknowledgments}

This work was supported by a grant from the Indian Council of Agricultura Research (ICAR). We thank staff members of Distributed Information Sub Centre (DISC), and Indian Institute of Spices Research for their support and encouragement.

\section{References}

1. Brasier CM (2009) Phytophthora biodiversity: How many Phytophthora species are there? Phytophthora in forest and natural ecosystem. USDA Forest Service: General Technical Report, Albany, CA, USA 221: 101-115.

2. Margulis L, Schwarts KV (2000) Five kingdoms: an illustrated guide to the phyla of life on earth. Freeman WH and Company, New York, USA.

3. Baldauf SL (2003) The deep roots of eukaryotes. Science 300: 1703-1706

4. Von't Slot KAE, Knogge W (2002) A dual role for microbial pathogen derived effector proteins in plant disease and resistance. Crit Rev Plant Sci 21: 229271.

5. Panabieres F, Ponchet M Allasia V Cardin C, Ricci P (1997) Characterization of border species among Pythiaceae: several Pythium isolates produce elicitins, typical proteins from Phytophthora spp. Mycol Res 101: 1459-1468.

6. Ribeiro OK (1978) A source book of the genus Phytophthora. Cramer J (Ed.) Germany 417

7. Nespoulous C, Huet JC, Pernollet JC (1992) Structure-function relationships of alpha-elicitin and beta-elicitin, signal proteins involved in the plant-Phytophthora interaction. Planta 186: 551-557.

8. Kamoun S, Lindqvist H, Govers F (1997) A novel class of elicitin-like genes from Phytophthora infestans. Mol Plant Microbe Interact 10: 1028-1030.

9. Peever TL, Higgins VJ (1989) Electrolyte leakage, lipoxygenase, and lipid peroxidation induced in tomato leaf tissue by specific and nonspecific elicitors from Cladosporium fulvum. Plant Physiol 90: 867-875.

10. Sasabe M, Takeuchi K, Kamoun S, Ichinose Y, Govers F, et al. (2000) Independent pathways leading to apoptotic cell death, oxidative burst and defense gene expression in response to elicitin in tobacco cell suspension culture. Eur J Biochem 267: 5005-5013.

11. Binet MN, Humbert C, Lecourieux D, Vantard M, Pugin A (2001) Disruption of microtubular cytoskeleton induced by cryptogein, an elicitor of hypersensitive response in tobacco cells. Plant Physiol 125: 564-572.

12. Mikes V, Milat ML, Ponchet M, Panabières F, Ricci $P$, et al. (1998) Elicitins, proteinaceous elicitors of plant defense, are a new class of sterol carrie proteins. Biochem Biophys Res Commun 245: 133-139. 
Citation: Vijesh Kumar IP, Reena N, Anandaraj M, Eapen SJ, Johnson GK, et al. (2013) Amplification, Cloning and In silico Prediction of Full Length Elicitin Gene from Phytophthora capsici, the Causal Agent of Foot Rot Disease of Black Pepper. J Plant Pathol Microb 4: 181 doi:10.4172/2157-7471.1000181

Page 6 of 6

13. Boissy G, de La Fortelle E, Kahn R, Huet JC, Bricogne G, et al. (1996) Crystal structure of a fungal elicitor secreted by Phytophthora cryptogea, a member of a novel class of plant necrotic proteins. Structure 4: 1429-1439.

14. Osman H, Mikes V, Milat ML, Ponchet M, Marion D, et al. (2001) Fatty acids bind to the fungal elicitor cryptogein and compete with sterols. FEBS Lett 489 : $55-58$

15. Boissy G, O'Donohue M, Gaudemer O, Perez V, Pernollet JC, et al. (1999) The 2.1 A structure of an elicitin-ergosterol complex: A recent addition to the Stero Carrier Protein family. Protein Sci 8: 1191-1199.

16. Kim YT, Oh J, Kim KH, Uhm JY, Lee BM (2010) Isolation and characterization of NgRLK1, a receptor-like kinase of Nicotiana glutinosa that interacts with the elicitin of Phytophthora capsici. Mol Biol Rep 37: 717-727.

17. Cooke DEL, Duncan JM (1997) Phylogenetic analysis of Phytophthora species based on ITS 1 and 2 sequences of the ribosomal RNA gene repeat. Mycol Res 101: 667-677.

18. Hall TA (1999) BioEdit: A user-friendly biological sequence alignment editor and analysis program for Windows 95/98/NT. Nucl Acids Symp Ser 41: 95-98.

19. Reese MG (2001) Application of a time-delay neural network to promote annotation in the Drosophila melanogaster genome. Comput Chem 26: 51-56.

20. Zdobnov EM, Apweiler R (2001) InterProScan--An integration platform for the signature-recognition methods in InterPro. Bioinformatics 17: 847-848.

21. Ceroni A, Passerini A, Vullo A, Frasconi P (2006) DISULFIND: A disulfide bonding state and cysteine connectivity prediction server. Nucleic Acids Res 34: W177-W181

22. Nielsen H, Engelbrecht J, Brunak S, von Heijne G (1997) Identification of prokaryotic and eukaryotic signal peptides and prediction of their cleavage sites. Protein Eng 10: 1-6.

23. Hall BG (2013) Building phylogenetic trees from molecular data with MEGA Mol Biol Evol 30: 1229-1235.

24. Thomsen R, Christensen MH (2006) MolDock: A new technique for highaccuracy molecular docking. J Med Chem 49: 3315-3321.

25. Bouaziz S, van Heijenoort C, Guittet E, Huet JC, Pernollet JC (1994) Resonance assignment, cysteine-pairing elucidation and secondary-structure determination of capsicein, an alpha-elicitin, by three-dimensional $1 \mathrm{H} \mathrm{NMR}$. Eur J Biochem 220: 427-438.

26. Ponchet M, Panabières F, Milat ML, Mikes V, Montillet JL, et al. (1999) Are elicitins cryptograms in plant-Oomycete communications? Cell Mol Life Sci 56 1020-1047.

27. Mikes V, Milat ML, Ponchet M, Ricci P, Blein JP (1997) The fungal elicito cryptogein is a sterol carrier protein. FEBS Lett 416: 190-192.

28. Karlofsky P, Prell HH (1991) The TRP1 gene of Phytophthora parasitica encoding indole-3-glycerolphosphate synthase- $\mathrm{N}$-(5'-phosphoribosyl) anthranilate isomerase: Sstructure and evolutionary distance from homologous fungal genes. Gene 109: 161-165.

29. Chen Y, Roxby R (1996) Characterization of a Phytophthora infestans gene involved in vesicle transport. Gene 181: 89-94.

30. Sharp PA (1994) Split genes and RNA splicing. Cell 77: 805-815.

31. Huet JC, Sallé-Tourne M, Pernollet JC (1994) Amino acid sequence and toxicity of the alpha elicitin secreted with ubiquitin by Phytophthora infestans. Mol Plant Microbe Interact 7: 302-304.

32. O'Donohue MJ, Gousseau H, Huet JC, Tepfer D, Pernollet JC (1995) Chemica synthesis, expression and mutagenesis of a gene encoding beta-cryptogein an elicitin produced by Phytophthora cryptogea. Plant Mol Biol 27: 577-586.

33. Ricci P, Bonnet P, Huet JC, Sallantin M, Beauvais-Cante F, et al. (1989) Structure and activity of proteins from pathogenic fungi Phytophthora eliciting necrosis and acquired resistance in tobacco. Eur J Biochem 183: 555-563.

34. Laugé R, De Wit PJ (1998) Fungal avirulence genes: structure and possible functions. Fungal Genet Biol 24: 285-297.

35. Joosten MH, Vogelsang R, Cozijnsen TJ, Verberne MC, De Wit PJ (1997) The biotrophic fungus Cladosporium fulvum circumvents Cf-4-mediated resistance by producing unstable AVR4 elicitors. Plant Cell 9: 367-379.

36. Panabières F, Marais A, Le Berre JY, Penot I, Fournier D, et al. (1995) Characterization of a gene cluster of Phytophthora cryptogea which codes fo elicitins, proteins inducing a hypersensitive-like response in tobacco. Mol Plant Microbe Interact 8: 996-1003

37. Sacks W, Nürnberger T, Hahlbrock K, Scheel D (1995) Molecular characterization of nucleotide sequences encoding the extracellular glycoprotein elicitor from Phytophthora megasperma. Mol Gen Genet 246: 45-55.

38. Osman H, Vauthrin S, Mikes V, Milat ML, Panabières F, et al. (2001) Mediation of elicitin activity on tobacco is assumed by elicitin-sterol complexes. Mol Bio Cell 12: 2825-2834.

39. Hendrix JW (1970) Sterols in growth and reproduction of fungi. Annu Rev Phytopathol 8: 111-130. 